AFRICAN

\title{
Tanzania's all-weather friendship with China in the era of multipolarity and globalisation: towards a mild hedging strategy*
}

by Jean-Pierre Cabestan Department of Government and International Studies Hong Kong Baptist University Jean-Raphaël Chaponnière Asia Centre, Paris

\begin{abstract}
How close is the Tanzanian-Chinese partnership today? Bi-lateral trade and Chinese economic presence in Tanzania are much bigger than in the 1970s; China's "no strings attached" policy is still attractive; political solidarities and military cooperation have remained quite strong. However, this bi-lateral relationship does not have the importance, nor the exclusiveness it enjoyed in the heydays of socialism. Today, China must compete economically, politically and culturally, with the activism and soft power of a larger group of countries, particularly the United States. Although both in Dar es Salaam and in Beijing this relationship has remained presented as "special", it has lost the structural role that it had until the late 1970s in shaping Sino-African relations. Instead, particularly since the mid-2000s, it is rather the growing Sino-American and Sino-Western competition in Africa that has structured Tanzania's foreign policy, convincing Tanzania to adopt what we would call a "mild hedging strategy" towards China and helping it, at least to some extent, to better defend its own interests.
\end{abstract}

* This research was partly funded by the Research Grant Council of Hong Kong Special Administrative Region (GRF No. HKBU 240110). 
AFRICAN

EAST-ASIAN

AFFAIRS

\section{Introduction}

There are two clearly distinct eras in the Tanzania-China close partnership: the socialist period, from 1964 to 1989 illustrated by well-known large scale symbolic Beijing-realised projects as the Urafiki Friendship Textile Mills in the 1960s or the Tanzania-Zambia railways (TAZARA) built in the 1970s; and the last 27 years, dominated in both countries by economic reforms, political changes and globalisation. The transition from one development model to another was a lengthy one, ${ }^{1}$ weakening the partnership until 2005 when it was revived by both sides in a very different ideological and geo-strategic environment (Wang, 2010; Walt, 2012).

What makes the Tanzania-China relationship different from other Sino-African bilateral partnerships are, in our view, both its initial closeness as well as the parallel, quasi-simultaneous and deep transformations of both countries after the end of the Cold War and the collapse of the Soviet Union. These transformations are far from having been identical: Tanzania gradually moved in the 1990s from a one-party system to a multi-party democracy while China has remained dominated by the Communist Party and authoritarianism. Nevertheless, in the 1980s structural economic reforms and liberalisation were introduced around the same time, allowing both countries to quietly move away from socialism. As will be observed, the result is that Tanzania has developed relations with a wider array of countries, including the most prominent Western powers, such as the United States (US) and the European Union (EU), as well as other emerging economies like India. Yet Tanzanian leaders continue to regard China as a close partner.

This paper's objective is to assess the current state of Tanzanian-Chinese relations in analysing the major features of this relationship with the help of the concept of hedging, particularly as Cheng-Chwee Kuik defines it (Kuik, 2008 \& 2016). The paradox and questions that we wish to address are the following: While economic interactions between Tanzania and China are today much denser than in the 1960s and the 1970s, why is their bi-lateral political and strategic partnership today weaker than in the past decades? What are the major international and domestic forces explaining this evolution? To what extent has Tanzania moved from a foreign policy bandwagoning China to what we would qualify as a "mild hedging strategy"? 


\section{AFRICAN \\ EAST-ASIAN \\ AFFAIRS

The "all-weather friendship" dynamic appears to remain the most common characterisation on both sides, however, this bi-lateral relationship does not have the importance, nor exclusiveness it enjoyed in the heydays of socialism when Julius Nyerere and Mao Zedong presided upon the destiny of their respective country. There is some irony here because, as will be observed, bi-lateral trade and Chinese economic presence in Tanzania are much bigger than in the 1970s, a consequence of China becoming the world largest exporter; moreover, political solidarities and military cooperation have remained quite strong. However, today China's diplomatic and economic influence on Tanzania is far from being overwhelming. In other words, as elsewhere in Africa and in the world, Tanzania's relations with China has been affected first by the end of the Cold War and since the mid-2000s by the growing Sino -American and Sino-Western geo-strategic, economic and ideological competition. As a result, although both in Dar es Salaam and Beijing this relationship has remained presented as "special", it has lost the structural role it had until the late 1970s in shaping Sino-African relations.

In other words, deep changes both in Tanzania's domestic economic and political environment and in the world order contribute to explaining the relative decline of the Sino-Tanzanian partnership. However, more importantly, has been the Tanzanian decision to embark into a new foreign policy that has been aimed at rebalancing its external relations and moving away from a bandwagoning policy towards China.

Tanzania is not the only African state to have become more active internationally and to enjoy in its negotiations with emerging powers a position that is stronger than many think (Vickers, 2013). It is true that Sino-Western relations in Africa, and especially in Tanzania, cannot only be looked at through the prism of competition: although all companies compete for market shares, whatever their nationality is, there is as much space for complementarity as for competition in Africa: moreover, Tanzania, as many African countries, do not want and do not have reasons to choose (Dollar, 2016: 97-98, Shinn, 2016).

However, perceptions matter and governments tend to see their action through the prism of competition (Hermann, 2013, Interviews 4, 5 and 6), particularly as the 
AFRICAN

EAST-ASIAN

AFFAIRS

world is moving from a unipolar towards a multipolar structure or even a kind of new and rather asymmetrical bipolarity (Tunsjø, 2011) between the US and China one superpower, one "emerging potential superpower" and a few great powers (Brooks and Wohlforth, 2016). In this new international environment, in order to better protect their interest, smaller countries need even more than the big ones to hedge against risks (Tessman, 2012: 205). That is precisely what Tanzania has been doing since the early 2000 s in order to reduce the systemic asymmetry of its relationship with China. While in this respect Tanzania's situation is not totally dissimilar from China's neighbours as Vietnam or Malaysia (Womack, 2010), it is far from having adopted what some international relations theorists such as Kuik would call a "balancing strategy" or even an "indirect balancing strategy": Tanzania is not trying nor able to contain China's influence or adopt full-fledge "risk-contingency options" and a "hedging strategy" (Kuik, 2008: 166, 171; Kuik, 2016: 502-506). However, if we keep using Kuik's terminology, our hypothesis is that the Tanzania government has moved from a "bandwagoning strategy" to an "insurance policy" that has kept elements of "binding engagement" with China but looks more and more as promoting "economic pragmatism". In other words, it has adopted what Kuik calls "returnsmaximising options" (Kuik, 2008: 502, Kuik, 2016: 502). Tanzania still accepts China's power but it also accepts and tend to welcome to a larger extent US and other Western countries' co-operation and influence. It has taken advantage of the growing China-Western strategic and economic competition to improve its bargaining power with both and reduce the undesired effects of a close but also asymmetrical relationship with China.

This article is based both on fieldwork conducted in 2012 in Tanzania and updated Tanzanian, Chinese and Western primary as well as secondary sources. Our method and approach have been to look at the Tanzanian-Chinese relationship from Tanzania's viewpoint and to reflect on this country's changing perceptions of China as well as of other partners. In this aim, we have chosen to interview a rather small but diverse and well-informed (around thirty) sample of Tanzanians as well as Chinese and Westerners living in Tanzania, including government officials, business people, diplomats and journalists, out of which one third has been quoted in this paper (see 


\section{AFRICAN \\ EAST-ASIAN \\ AFFAIRS

bibliography).

In order to better comprehend the scope and the limits of today's Tanzania-China partnership, we will first analyse the key facets of these two countries' political relations since 2005: the Chama Cha Mapinduzi (CCM)-Chinese Communist Party (CCP) party-to-party relations, the foreign policy convergences between both countries and their limits, and their strong military co-operation since its revival since 2005. Then, we will briefly present Tanzania-China economic relations, not only their bi-lateral trade but also Chinese investments in Tanzania before looking at the financial dimension of this partnership.

\section{Today's Tanzania-China political and security partnership and its limits}

Tanzania's political democratisation and the opening of its economy in the early 1990s contributed to strengthening its relations with the West, particularly the US, the United Kingdom (UK) and the European Union (EU) and loosening its traditional links with the former Soviet Union and China. The rise of new security threats such as Islamic terrorism in the late 1990s have directly contributed to intensifying this rapprochement.

It was in this context that both Tanzania and China decided in 2005 to re-dynamise their relationship. Owing to both countries dramatic domestic changes and China's unprecedented need for African resources, this relationship had to be based on new foundations. Jakaya Kikwete's election as Tanzania's president in 2005 and Prime Minister Wen Jiabao's visit the following year signalled this new departure in the relationship. Since then both governments have continued to claim their adherence and pay lip service to "socialism" and to praise their "all-weather friendship" (quantianhou youyi). However, it was clear that the Tanzania-China relationship was becoming much more pragmatic and business-oriented. Moving away from keeping afloat the older projects launched in the 1960s and 1970s, as the famous TAZARA, Beijing decided to rapidly increase and diversify its economic presence in this country, in an attempt to catch up with Tanzania's other (and new) partners.

Since 2005, high level visits have intensified. President Kikwete travelled to China 
AFRICAN

EAST-ASIAN

AFFAIRS

three times: in 2006, on the occasion of the third Forum on China-Africa Cooperation (FOCAC), in 2008 and in October 2014 to celebrate the $50^{\text {th }}$ anniversary of the establishment of diplomatic relations between the two countries. Chinese President Hu Jintao and his successor Xi Jinping made important visits to Tanzania, in 2009 and 2013 respectively.

The forms of China's co-operation with Tanzania have remained partly identical: when in Dar es Salaam, Hu inaugurated a US\$ 56 million sports complex largely funded by China. He also launched new initiatives like signing a US\$ 17.5 million agreement to finance investments in agriculture and another to send Chinese volunteers to Tanzania, a project that can be compared to the US Peace Corps (Shinn and Eisenman, 2012: 263). While since the 2006 FOCAC meeting China's co-operation with Tanzania has largely focused on agriculture, Beijing has further encouraged its entrepreneurs to trade with or invest in Tanzania: for example, in 2008 an unprecedented China-Africa business forum comprising 300 delegates was held in Dar es Salaam.

Chinese Minister of Commerce Chen Deming's visit to Tanzania in 2010 also confirmed China's intention to deepen its co-operation with the country. Chen signed four agreements, including a US\$ 180 million optic fibre deal and another one related to the construction of Zanzibar airport's second terminal worth US\$ 70 million. Similarly, in March 2013, Xi Jinping's visit signalled the go-ahead for the Chinese financing of a US\$ 10 billion port construction in Bagamoyo, due for completion in 2017 (the whole project will not be completed before 2025 for domestic political and financial reasons) (Reuters, 16 October 2015). ${ }^{2}$ On a visit to China in October 2014, Kikwete signed nine agreements related in particular to agriculture, the creation of industrial parks and finance. Moreover, in February 2014, both countries signed a bilateral Air Service agreement aimed at establishing direct flights between them and their airline companies and setting up a joint venture to strengthen regional aviation co-operation. ${ }^{3}$

It is fair to say that Kikwete has been satisfied with Tanzania's co-operation with China. In 2007, he went as far as to declare, in a clear reference to this country's "no 


\section{AFRICAN \\ EAST-ASIAN \\ AFFAIRS

strings attached policy", that it was easier to do business with China than the West because, "China does not ask many questions like the West do" (Financial Times 2007, quoted by Kamata, 2014: 94). ${ }^{4}$ While this feeling may be shared by a number of African leaders, does this remark genuinely encapsulate the nature of TanzaniaChina relations? As shown below, it does not.

This partnership has remained very close and specific at a number of levels: party-toparty relations, foreign policy, defence co-operation and to some extent business. After his election in October 2015, the newly elected Tanzanian President, John Magufuli, declared to Zhang Ping, Vice-Chairman of China's National People's Congress, who represented Xi Jinping at his inauguration: "we should strengthen our bi-lateral relation with a view to helping Tanzania to achieve its development goal and enable me to fulfil my promise of improving the life standards of Tanzanians". 5 But a month later, Magufuli decided not to participate in the FOCAC in Johannesburg but to send his deputy, Vice-President Samia Suluhu Hassan, and a much smaller delegation (six members) than usual. ${ }^{6}$ He preferred to take part in the Commonwealth summit held in Malta a week earlier and the Paris COP21 Conference on Climate. This symbolic choice tends to signal that in spite of the revival of SinoTanzanian relations since 2005, Tanzania's economic and political reforms have moved closer to countries that see China as a trade competitor, if not always a strategic rival (Minde, 2016).

\section{Contested Party to Party Relations}

Today, the CCM, the Revolutionary Party and ruling party of Tanzania, has kept strong ties with the CCP. And on the domestic stage, it has maintained to some extent the influence and modus operandi that stemmed from its previous status.

Both parties regularly exchange high level visits and experiences, China's "success story" remains, at least on paper, a major source of inspiration for the CCM and Tanzanian reforms. Here it should be noted that China has not tried to set up formal relations with Tanzania's other political groupings, not even the ones represented in the Bunge (National Assembly) such as the CHAMEDA (Party for Democracy and Progress) or the Civil United Front (Interview 6). The CCP may for example feel un- 
AFRICAN

EAST-ASIAN

AFFAIRS

comfortable with the CHAMEDA, a party of centre-right (and anti-corruption) orientation that has also kept close relations with the US (its representative took part in the US Democrats' Convention), the EU or India (Interview 7). However, at the same time, Tanzanian opposition parties are not all critical of China; CHAMEDA is $^{7}$; most of them also support a strong, and sometimes a stronger, "more aggressive" engagement with China (Interview 7).

On the Tanzanian side, the CCM-CCP relationship has remained a useful channel to reach out to China's top leaders and perpetuate a feeling of coziness with China's political elite. China is also taken as an example by the CCM to legitimise the current economic reforms in the name of "socialism" and its necessary adaptation to globalisation. On the Chinese side, this party-to-party relationship is perceived as a useful tool to better penetrate and influence Tanzania's ruling elite and export China's development model, even if Chinese officials often argue that there is not such a model and each country should follow its own path (Hanauer \& Morris, 2014: 9). ${ }^{8}$

In any case, $\mathrm{CCM}-\mathrm{CCP}$ exchanges and co-operation seem to be more pro-actively promoted by China than by Tanzania, even if the CCM is far from being indifferent to its relationship with the CCP. For example, on 25 June 2014, when Chinese VicePresident Li Yuanchao met Philip Mangula, Vice-Chairman of CCM in Dar es Salaam, $\mathrm{Li}$ "raised a three point proposal to develop the two parties' relations. He called on the two parties to maintain a high level of communication and deepen mutual political trust, to expand cadres exchanges and intensify communication on governance experience and to work together to hold multilateral activities to boost Chinese-African relations". ${ }^{9}$ Likewise, on 4 July 2014, both leaders met again at the University of Dar es Salaam and "discussed how socialism can survive the modern era". Tanzanian academics taking part in this forum presented papers on the topic. Philip Mangula reiterated that Tanzania was a socialist nation drawing lessons from China, which he described as "a leading socialist country in the world."10

These meetings and statements tend to underscore that both parties are trying to keep alive a fledging relationship that has lost most of its substance. Besides, the CCMCCP special relationship has been questioned, both by opposition parties and even 


\section{AFRICAN \\ EAST-ASIAN \\ AFFAIRS

some members of the Tanzanian government. For example, in September 2013, the presence of the Chinese ambassador Lü Youqing at a CCM political rally chaired by secretary general Abdulrahman Kinana in Kshapu, Shinyanga region, triggered a statement from the Tanzanian Ministry of Foreign Affairs and International Cooperation arguing that the Chinese ambassador had crossed the line and breached article 41(1) of the Vienna Convention of 1961, which requires that foreign diplomats keep off the domestic affairs of their host countries, political events included. Opposition party CHADEMA threatened to write a protest letter to the Tanzanian and Chinese governments as well as the United Nations (UN) if no action was taken against the diplomat. Similar incidents involving Chinese diplomats occurred previously in 2010 and 2012. ${ }^{11}$ Reported in the local press, this incident shows that, because of Tanzania's democratic environment, the CCM-CCP relationship is more contested today.

Cadres exchanges and seminars will contribute to keeping both parties interacting and China influencing Tanzania's ruling party elite. However, this relationship is more rooted in the past than in the future of the two countries' relations.

\section{Weakening Foreign Policy and Geo-Strategic Convergences}

Today, as shown below, the foreign policy and geo-strategic convergences between Tanzania and China have been weakening. While we can trace back the origins of this loosening partnership to the end of the Cold War, China's rise and its growing competition with the US, including in Africa, have persuaded Tanzanian leaders, particularly since Kikwete, to rebalance their country's foreign policy orientations in favour of the latter and diversify (Mponzi, 2014). While China has concentrated on boosting trade and economic relations, the US, particularly under Obama has relaunched its co-operation with Tanzania in putting more financial resources in the country, promoting public-private partnerships, and including Tanzania in his "Power Africa Initiative" (Hanauer \& Morris, 2015: 101-102).

It is clear that China is still today one of Tanzania's key diplomatic partners. Also, China still considers Tanzania as one of its main diplomatic partners and geostrategic hubs in East Africa (Interview 3, Alden and Alves, 2008: 51). Tanzania's geo- 
AFRICAN

EAST-ASIAN

AFFAIRS

graphical location on the Western edge of the Indian Ocean clearly matters in Beijing's eyes.

Nevertheless, as early as the late 1980s, Tanzania gradually moved away from its anti-Western leanings, establishing a better balance among its main partners, the US, EU, China and India. Partnerships' diversification was already the key word. Today, some members of the Tanzania government still want to move more decisively eastward, not only towards China but also India, Japan and South Korea (Interview 3). Simultaneously, there have been repeated calls among the Tanzanian elite to cooperate more with the BRICS (Brazil, Russia, India, China and South Africa). ${ }^{12} \mathrm{Nev}$ ertheless, after Kikwete's election in 2005, Tanzania started to actively strengthen its relations with the West, and particularly the US (Interview 5). At the same time, Kikwete decided to develop military co-operation with Germany and the US, moving partly away from Tanzania's traditional arms suppliers such as China and more importantly Russia.

Conversely, the US has also established a stronger presence in Tanzania after the bombing of its Embassy in Dar es Salaam in 1998. Kikwete was the first African leader to meet with newly-elected President Obama in Washington DC in 2009. ${ }^{13}$ Obama actually pursued and consolidated a closer co-operation initiated by the Bush administration which, among other things, had set up in 2004 a large Millennium Challenge Corporation (MCC) grant, which doubled US aid but also linked it to progress in political and economic freedom, rule of law as well as governance. Since 2006, Tanzania has benefited from this grant, signing in 2008 with the MCC a sixyear and US\$ 698 million "compact" aimed at modernising its transport, energy and water sectors. ${ }^{14}$ Since 2014 , the MCC has developed other projects related for instance to improving public power utilities. ${ }^{15}$

In the same period, China's Africa policy has expanded and also diversified, reducing to some extent Tanzania's privileged position. In Chinese leaders' eyes, Kenya has emerged as a more important political and trade partner because of the weight of its economy, its higher standard of living and its regional influence (several signifi- 


\section{AFRICAN \\ EAST-ASIAN \\ AFFAIRS

cant regional organisations are based in Nairobi) (Shinn and Eisenman, 2012: 266269; Onjala, 2014). For example, it is not a coincidence that in 2006 Beijing decided to establish the African desk of its radio and television stations in Nairobi and to broadcast in English, Swahili and Chinese from there (Wasserman, 2015; Zhang et al., 2016; Interview 10).

It is likely that China's proposed development of ports (as in Bagamoyo) and supporting hinterland infrastructure on the East coast of Africa serves greater geostrategic interests within Africa and the Indian Ocean. And since late 2013, these interests have been "repackaged" by Beijing in Xi Jinping's "One Belt One Road" initiative, and particularly its "Maritime Silk Road" facet. Can we, however, consider these new ports as part of a "string of pearls" in which each pearl is a "a nexus of Chinese geopolitical influence or military presence" (Pehrson, 2006: 3)? Is the economic and political rivalry between India and China the $21^{\text {st }}$ century equivalent of the "great game", whose contending sphere of influence includes the littoral states of the eastern Indian Ocean (Scott, 2008: 2)?

As Anthony indicates:

The broader market economic system in which China and Africa engage today entails that Chinese unfettered access to projects is complicated by the interests of multiple stakeholders. The Chinese presence has been exaggerated at the expense of other actors and thus, in any future conflict, it cannot be assumed that China will be able to mobilise this infrastructure in its interests. This has implications for the broader analysis of China's growing presence in the Indian Ocean (Anthony, 2013: 134).

More pragmatically and in a shorter future, Bagamoyo and other infrastructure projects built by China in Tanzania will contribute both to decongestioning the existing ports in the region (particularly Mombasa and Dar es Salaam) and getting an easier access to the raw materials that Beijing wishes to import (natural gas) from and the markets it hopes to reach in Eastern Africa, particularly in the Great Lake region. 
AFRICAN

EAST-ASIAN

AFFAIRS

The decision announced by China in November 2015 to open a dual use logistical base operated by the People's Liberation Army (PLA) Navy in Djibouti, a much more secure and strategically better located place where France, the US and Japan already have military facilities, confirms also the overly economic and trade dimension of the Bagamoyo project. ${ }^{16}$ Moreover, if in the longer run, Bagamoyo and other Tanzanian ports are used as supply or logistical bases for PLA navy ships cruising in the region, will this role be different from the ports (as Djibouti or Salalah) where the PLA ships involved in the anti-piracy operations in the Gulf of Aden make regular calls?

More generally, the Tanzania-China political and diplomatic relations lack depth and engagement. As indicated in a Tanzanian action plan in 2009, "interaction generally appears to be extremely formal" (quoted by Shinn and Eisenman, 2012: 263). China is a useful partner and alternative to Western aid and investments. As Former Tanzanian President Benjamin Mkapa declared in China in 2014:

China's relations with the Western countries in the African market should be competitive... China should not be seen as collaborating with them [Western countries] to stifle Africa's efforts to lift its people from poverty and disease. ${ }^{17}$

In other words, as for other African countries, it is in Tanzania's interest that the West and China (or other emerging economies) continue to compete. Likewise, it is also in its interest to keep a diplomatic and geostrategic balance between the two groups of nations and to explore more "returns-maximising options" vis-à-vis China. As Shinn and Eisenman indicated, the Tanzanian government "understands the potential risk in a monopoly position for Chinese contractors and unfavourable deals tied to Chinese assistance" (2012: 263). However, this potential risk looks more and more remote today, even if Tanzania-China military co-operation has intensified since 2000 .

\section{An enhanced military co-operation}

Rooted in the history of their bi-lateral relations, military co-operation between Tan- 


\section{AFRICAN \\ EAST-ASIAN \\ AFFAIRS

zania and China has intensified in the 2000s and particularly since 2010. In the last decade, Tanzania has been China's second client in terms of arms sales to Africa (US\$ 399 million from 2000 to 2015 and 13 per cent of China's total arms sales to Africa), behind Algeria (US\$ 438 million) and Egypt (US\$ 424 million), and its first in Sub-Sahara Africa (SIPRI, 2015). Chinese arms sales to Tanzania have increased in the last few years (US\$ 352 million in 2009-2015, 17 per cent). Moreover, Beijing is involved in ambitious military infrastructure and communication projects. However, Tanzania has started looking for military co-operation with other countries, such as the US or Germany which have contributed to reducing China's influence on the Tanzania People's Defence Forces (TPDF) (Kalu and Kieh, 2014).

In 2000, PLA Navy ships started to visit Tanzania. China's participation in the antipiracy operations in the Gulf of Aden has directly increased the frequency of these visits including the call of PLA's main Hospital ship, the Peace Ark (Heping zhi zhou) in Dar es Salaam in 2010. These visits have triggered some anxieties among Western nations, particularly the US that understands them as part of a Chinese willingness to establish military bases in warm sea ports (Interview 5). However, what the PLA Navy is wishing to secure in the foreseeable future are port calls, resupply and "rest and relaxation" (R\&R) facilities for its personnel, services that Djibouti more than Dar es Salaam or perhaps Bagamoyo can better provide. Training has also intensified, particularly since 1997, when exchanges of military delegations started to increase again. According to Beijing, 1,000 Tanzanian military personnel receive training in China every year (Interview 6).

In the 1990s China's armament supplies to Tanzania mainly constituted of light weapons or donations. Since the early 2000s, the TPDF have started (again) to buy heavier equipment, such as transport aircrafts (two Yun-8F 200) in 2002 and Armoured Personnel Carriers in 2005. This trend has accelerated since then, including 30 tanks 59G in 2007, 14 fighter aircrafts F-7MG in 2008 and six training/combat fighters K-8 (Karakorum) in 2010 (SIPRI, 2015). Besides, in April 2015, President Kikwete commissioned two navy ships built by China's Poly Technologies; their mission is to enhance the fight against illegal fishing and piracy. ${ }^{19}$ 
AFRICAN

EAST-ASIAN

AFFAIRS

China has also been involved in the construction of military infrastructures such as the National Defence College built by a Chinese company, financed by both governments and handed over to the TPDF in January 2011 (Kamata, 2014: 96). And in 2015, it funded two projects aimed at improving the Ngerengere Air Force base and equip it with the capacity to receive large passenger planes whenever there is an emergency at the Julius Nyerere International Airport in Dar es Salaam. ${ }^{19}$

More importantly, later in 2011, China accepted to finance with a concessional loan of US\$ 64 million from the Export-Import (Exim) Bank the establishment of an Independent Secured Mobile Network Project under the Ministry of Defence and National Service. This project aims to lower communication costs and link all defence forces with modern and secured communication network as well as allowing sharing of information. ${ }^{20}$ Beijing's direct involvement in the establishment of secured communication in the TPDF has been the cause of multiple speculations in the Western diplomatic community based in Dar es Salaam (Interviews 4 and 5). It is worth noting that the Chinese Embassy in Tanzania does not have a defence attaché: again, informed sources claim that, the PLA being directly represented by a unknown number of officers in the TPDF, there is no such need (Interviews 4, 5 and 6).

Since the early 2000s, Tanzania has tried to diversify its arms suppliers, getting weapons or military equipment from Ukraine and Western countries such as the UK, Germany, Italy (IVECO transport vehicles, helicopters), the US (patrol boats) and for light weapons, South Africa. Some of the equipment is donated. However, volumes have remained small according to UN data. ${ }^{21}$ The TPDF have in addition maintained a small co-operation with Cuba and North Korea (Interview 5). The American government has also been involved in military personnel training. The US is willing to give Tanzania a role in Africom, organising joint exercises with East African countries and training Tanzanian soldiers for UN Peace-Keeping Operations or antipiracy and anti-terrorism missions (Interview 8).

Some observers argue today that for its defence also, Tanzania has moved closer to the US than China. Nevertheless, Beijing has remained Tanzania's top weapons suppliers -92 per cent of its imports in value between 2000 and 2015 and over 99 per 


\section{AFRICAN \\ EAST-ASIAN \\ AFFAIRS

cent between 2009 and 2015 according to SIPRI (SIPRI, 2015) — and, even if one cannot fully trust SIPRI data that partly clash with UN figures, has clearly intensified its military co-operation with Dar es Salaam, creating an obvious tension with Tanzania's foreign policy and geo-strategic priorities since the early 2000s. But China's cheaper armament and more generous military co-operation is likely to perpetuate this mismatch in the foreseeable future.

\section{Economic Relations: China as a Big Player Among Several}

As elsewhere in Africa, China has become the largest supplier of Tanzania and Tanzanian exports have recently been impacted by China's economic slowdown. Chinese investments have increased and Chinese firms are heavily involved in the construction sector and Chinese banks are significant creditors. However, other partners continue to play an important and, arguably, increasing role in Tanzania's external economic relations.

\section{Bi-lateral Trade: A North-South Pattern}

China is Tanzania's first trade partner but it is rather a supplier than a client. In 2015 Tanzania imported 34.7 per cent of its goods from China. ${ }^{22}$ Since 2000, even though the bi-lateral trade has grown forty-fold, ${ }^{23}$ China remains the third largest importer from Tanzania (8.1 per cent of this country's exports) after India (21.4 per cent) and the EU (16.7 per cent). ${ }^{24}$ According to Global Trade Atlas (GTA) statisticsdifferent from Comtrade's - China's exports to Tanzania kept increasing rapidly in 2015 and fell by 9 per cent in 2016 (January to August), while Chinese imports from this country stagnated in 2015 and fell by 40 per cent in 2016 (January to August) as China's growth slackened and price of commodities decreased. ${ }^{25}$ Like most non-oil African countries, Tanzania runs a structural trade deficit with China (nearly US\$4 billion in 2015), which represents more than eight per cent of its gross domestic product (GDP).

While China-Tanzania trade participates to the development of South-South relations, its composition has a typical North-South pattern as China exports manufactured goods and imports natural resources (Chaponnière, 2009). According to the 
AFRICAN

EAST-ASIAN

AFFAIRS

United Nations Industrial Development Organisation (UNIDO), competitiveness report (2012), this bias increased in the 2000s as the share of Tanzanian manufactured exports diminished. A disaggregation of Tanzanian exports show that their primary nature increased between 2002 (average 2001-2003) and 2013 (average 2012-2014): among the 10 largest items-which account for 91 per cent of Tanzanian exports to China-the share of manufactured and processed goods decreased from 12 per cent to nil, while that of metal products increased to 50 per cent. ${ }^{26}$

The structure of Tanzanian imports from China is less concentrated than its exports to China. However, they are dominant in the Tanzanian market. A comparison of the 10 largest items shows that equipment and durable goods have gained ground at the expense of consumer goods and semi processed products. Chinese market share is over 50 per cent for several items: over two third of imported motorcycles and 80 per cent of imported pipes are Chinese. ${ }^{27}$

As elsewhere in Africa, textile firms, including China's built and painfully restructured in the 1990s (Lee. 2009: 650-660), Friendship Textile Corp. in Urafiki, suffered from Chinese imports competition which increased four-fold to represent 45 per cent of Tanzanian textile and leather imports (Rutaihwa and Mkwawa, 2011): Chinese competition has probably contributed to the slowing down of textile production which indices fell from 271 in 2006 to 186 in 2011 (index 100 in 1985). According to the revised National accounts statistics published in November 2014, the share of manufacturing value added in GDP (seven per cent) has hardly changed since 2002 .

\section{Investments: from a low to high profile}

Foreign Direct Investment (FDI) in Tanzania picked up in the 2000s and have averaged US\$ 1.8 billion per year since 2010; according to United Nations Conference on Trade and Development (UNCTAD) (2015), its stock, US\$ 17 billion in 2014three times that of Kenya-is the largest in East Africa. Tanzanian Investment Centre (TIC) data show that South Africa, the UK and Canada account for 70 per cent of inflows. In 2013, Singapore was the largest investors as its sovereign wealth fund 


\section{AFRICAN \\ EAST-ASIAN \\ AFFAIRS

(Temasek) bought a 20 per cent share (for US\$ 1.3 billion) in the Tanzanian gas fields (UNCTAD, 2014: 19).

According to TIC, China is a minor investor in Tanzania as inflows averaged US\$ 5 million per year between 2005 and 2010 and Chinese presence is made of 140 enterprises and a cumulative investment of US\$ 200 million. Exploiting a Mofcom (China's Ministry of Commerce) database, which gives only the number of projects, David Dollar (2016) found 160 Chinese projects in Tanzania: 30 in manufacturing and 110 in service and 20 in agriculture. According to the Chinese Embassy in Dar es Salaam ${ }^{28}$ with investment reaching US\$ 4 billion in 2014 China could be the largest investor in this country. ${ }^{29}$ An alternative source is provided by the China global tracker database ${ }^{30}$ which documents Chinese equity financed projects over US\$ 100 million.

However, low productivity, high overall production costs and a lack of qualified labour force have continued to limit Chinese investments in Tanzania' manufacturing industry (Jansson, 2009; Kweka and Lu, 2013; World Bank, 2014; Wangwe et al., 2014). And when Chinese enterprises invest in Tanzania, it is more for entering the local market and competing with Indian goods rather than for exporting (Interviews 1, 2 and 9).

\section{Building infrastructure}

As a result, China's main involvement in Tanzania has remained concentrated in the infrastructure sector. According to Mofcom data, the amount of international contracts won by Chinese companies in Tanzania rose from US\$ 0.3 billion in 2003 to US\$ 1.7 billion in 2013. They represent a significant percentage (12 per cent in 2013) of Tanzanian gross domestic investment. These contracts include the construction of an already mentioned US\$ 10 billion container port in Bagamoyo (2013) and a US\$ 1.7 billion satellite city to ease congestion in Dar es Salaam (2014). The announcement in June 2015 of the conclusion of a rail contract between the Tanzanian Transports Ministry and China Railway Materials (CRM) amounting US\$ 9 billion and aimed at linking Dar es Salaam to the country's western border and particularly the Kigoma Special Economic Zone (SEZ) $(2,600 \mathrm{~km}$ ), if 
AFRICAN

EAST-ASIAN

AFFAIRS

implemented, will probably strengthen China's position in the infrastructure sector and in this SEZ. ${ }^{31}$ Among the advantages enjoyed by Chinese contractors there is their availability to offer a "package" which includes financing.

\section{Finance: China as a free rider?}

According to Tanzania Ministry of Finance bulletin, disbursement of Chinese loans increased from US\$ 299 million in 2010, to US\$ 743 million in 2012 and US\$ 1.4 billion in 2015: cumulative disbursement reached over US\$ 4 billion (2010-2015) while during the same period total disbursement by official lenders stood at US\$ 8.3 billion. In addition to China Exim Bank, Beijing's major official lender, and private lenders, China's ZTE has made a US\$ 300 million loan for financing telecom projects in Tanzania.

Outstanding Tanzanian external debt increased from US\$ 7.8 billion (2010) to US\$ 19 billion by September 2015. Thus, China's share of this increase is significant (around one third) and its share of outstanding external debt should be around 20 per cent, knowing that there are lingering doubts on Tanzania's external debt data and discrepancies between sources (Chauvin, 2012). The significant rise in debt service payments from three per cent to eight per cent of total public expenditure cannot be explained by China's "free rider attitude": Chinese loans are considered as semiconcessional by the Tanzanian Ministry of Finance as their conditions are rather favourable: Libor plus 200 bps interest rate, a five year average grace period and a maturity of 25 years.

Since the early 2000s, Tanzania's economic relations with China have expanded but its dependence upon the world's second economy has been reduced. Trade relations have increased dramatically and become more asymmetrical, elevating China in Tanzania's first trade partner, way ahead of India (15.4 per cent). However, China is not Tanzania's major export destination. Beijing is involved in a growing number of infrastructure projects but it is not yet among Tanzania's top foreign investors, even if the statistics may underestimate the amount of Chinese FDI. In addition, China is somewhat distracted in trying to keeping afloat some of the most symbolic projects launched in the socialist era, such as the TAZARA. ${ }^{32}$ China did contribute to 


\section{AFRICAN \\ EAST-ASIAN \\ AFFAIRS

increasing Tanzania's external debt but in less proportion than in the case for other East African countries, notably Ethiopia. Overall, China has gained influence in Tanzania through trade in goods and services (construction), and Chinese investment will probably increase. However, it is only one big player among several. And in order to "maximise its returns", Dar es Salaam is keen to diversify its external economic relations to the benefit of India, the EU or its own neighbours (Mponzi, 2014; Interview 7, 8 and 9).

\section{Conclusion}

There is no doubt that the Tanzania-China partnership has remained politically strong. The frequency of visits since 2005 , the special connection between the CCM and the CCP, the density of the bi-lateral military co-operation and the increase of goods and people flows between both countries illustrate the closeness and longevity of this relationship. Nevertheless, the old socialist "friendship" and solidarity between Dar es Salaam and Beijing have not really helped to adapt this partnership to the new neo-liberal international environment. In addition, China's rise has fed Tanzanian elites' growing criticism of the "one-way" nature of the China-Tanzania relationship (Biketeye, 2013) or what we would call its "structural asymmetry" and more importantly its North-South feature (Sigalla, 2014). It has also convinced Dar es Salaam to rebalance its foreign relations in favour of other partners, particularly the US and the EU but also India and to move from bandwagonging China to a more cautious, "pragmatic" and "returns-maximising" hedging policy. In that respect, in our view, the Tanzania-China relationship is not as special as both governments claim and can be compared to other changing Africa-China relations (Cabestan, 2015).

This evolution has also included a significant political and security dimension as the US and the EU have been eager, particularly since the late 1990s, to develop a stronger partnership in these areas with Tanzania. Dar es Salaam's gradual diplomatic adjustment in favour of the West, therefore, can be understood as a dependent variable of the growing Sino-US economic and geo-strategic competition in Africa. 
AFRICAN

EAST-ASIAN

AFFAIRS

It is clear that Tanzania will continue to cultivate China both politically and economically as well as in terms of military co-operation, welcoming its highly competitive large-scale projects and, when need be, play it against its other partners (and vice-versa). However, mildly hedging against China, Tanzania's new foreign policy orientation has led to a relative decline of China's political and economic influence in Tanzania and to the emergence of stronger political and security links with the West and particularly the US.

In other words, this brief analysis of Tanzania-China relations contributes to nuancing the assessments about the growing Chinese imprint in Africa (Rotberg, 2008; Taylor, 2009) as well as Beijing's capacity to translate its growing economic and human interactions with Africa into political influence (Sun, 2014: 26-30); underscores the diversity of actors present on this continent (Li \& Farah, 2013; Taylor, 2014) and, more importantly perhaps, highlights African countries more active and reactive behaviour vis-à-vis the planet's only "emerging potential superpower" (Hanauer \& Morris, 2014). However, in the asymmetrical multi-polar world in which we are today, this conclusion should not be surprising including for China which has been a strong promoter of this new world order.

\section{Endnotes}

1. From a state-led pro rural strategy in the 1960 s and 1970 s to a more liberal strategy recently inspired by Malaysia and illustrated by Tanzania's "Big Fast Results" initiative.

2. See Reuters, 16 October 2015, http://af.reuters.com/article/kenyaNews/ idAFL8N12G3FZ20151016

3. See http://www.eturbonews.com/42807/tanzania-and-china-sign-new-bilateral-air-services-agreement

4. See Financial Times, 6 November 2007, http://www.ft.com/cms/s/0/d8a07e28 -72a3-11dc-b7ff-0000779fd2ac.html\#axzz25D4cJLSi. 
AFRICAN

EAST-ASIAN

AFFAIRS

5. See The Citizen, 7 November 2015, http://www.thecitizen.co.tz/News/JPMappeals-for-more-China-support/-/1840406/2946088/-/fygyat/-/index.html

6. See The Citizen, 6 December 2015, http://allafrica.com/ stories/201512090299.html

7. See "China is morally bankrupted all they need is oil and minerals", 31 March 2013, http://chademadiaspora.blogspot.hk/2013/03/china-is-morallybankruptall-they-need.html

8. See Xinhua, 21 June 2012, http://english.sina.com/ china/2012/0619/478579.html

9. See Xinhua, 24 June 2014, http://za.china-embassy.org/eng/znj1/ t1168704.htm

10. See The Citizen, 25 June 2014, http://tz.china-embassy.org/eng/ddbd/ t1171663.htm

11. See The Citizen, 17 September 2013. http://www.thecitizen.co.tz/News/China -envoy-at-CCM-rally-irks-Chadema/-/1840392/1995274/-/item/0/-/ans27bz/-/ index.html, and The Citizen, 18 September 2013, http://www.thecitizen.co.tz/ News/China-envoy-at-CCM-rally-irks-Chadema/-/1840392/1995274/-/ item/0/-/ans27bz/-/index.html

12. See Benjamin Mkapa's speech,"Unscrambling Africa in the New Millennium", given at Zhejiang Normal University on 23 September 2014, http://bridgingthegreatwall.wordpress.com/2014/09/23/ask-not-what-theforeign-nations-are-doing-for-africa/

13. See Allafrica, 22 May 2009, http://allafrica.com/stories/200905220750.html

14. See https://www.mcc.gov/where-we-work/program/tanzania-compact

15. See https://www.mcc.gov/where-we-work/country/tanzania

16. See The New York Times, 27 November 2015. 
AFRICAN

EAST-ASIAN

AFFAIRS

17. See Benjamin Mkapa's speech given at Zhejiang Normal University on 23 September 2014, http://bridgingthegreatwall.wordpress.com/2014/09/23/asknot-what-the-foreign-nations-are-doing-for-africa/

18. See News Ghana, 29 April 2015, http://www.spyghana.com/tanzanianpresident-commissions-2-new-navy-ships/

19. See Tanzania Daily News, 22 October 2015, http://allafrica.com/ stories/201510220376.html

20. See Daily News, 22 November 2011.

21. US\$ 1.5-1.6 million of arms and ammunitions each year in 2012-2014, most them bought from the US (US\$ 1 million) and far behind the Czech Republic, Italy, South Africa and the UK, see http://comtrade.un.org/data/

22. See http://trade.ec.europa.eu/doclib/docs/2011/january/tradoc_147401.pdf

23. According to Global Trade Atlas statistics, China-Tanzania trade increased from US\$ 0.09 billion in 2000 to US\$ 3.8 billion in 2014 (6 month annualised).

24. Since some Chinese goods transit through Dubai and South Africa, Chinese market share (12 per cent) is probably higher.

25. See http://www.gtis.com/gta and http://www.trademap.org/tradestat/ Country_SelProductCountry_TS.aspx

26. See www.trademap.org/tradestat/Country_SelProductCountry_TS.aspx

27. Ibid.

28. See http://www.tanzaniainvest.com/industry/china-invest-dar-es-salaam

29. However, these figures may add FDI and construction contracts.

30. Consulted at http://www.heritage.org/research/projects/china-globalinvestment-tracker-interactive-map, August 20 2014. As these projects necessitate some years to be implemented, they may be considered as 
AFRICAN

EAST-ASIAN

AFFAIRS

"leading indicators" which underestimate the number of investments as the majority of Chinese firms are small and medium sized (UNCTAD, 2014).

31. See Global Construction Review, 4 June 2015, http:// www.globalconstructionreview.com/markets/chinese-firms-wi8n-9bntanz6anian-rail-sch6eme/

32. See Reuters, 10 November 2015, http://af.reuters.com/article/topNews/ idAFKCN0SZ1LW20151110 and Railway Gazette, 11 November 2015, http://www.railwaygazette.com/news/traction-rolling-stock/single-view/view/ tazara-takes-delivery-of-locos-and-coaches.html

\section{Bibliography}

Alden, Chris and Alves, Christina. 2008. History \& Identity in the Construction of China's Africa Policy, Review of African Political Economy, 35(1):43-58.

Anthony, Ross. 2013. Infrastructure and Influence: China's presence on the coast of East Africa, Journal of the Indian Ocean Region, 9(2):134-149.

Biketeye, Alex. 2013. What Xi Jinping's visit to Tanzania means, The Citizen, 20 March 2013.

Brooks, Stephen G., and Wohlforth, William C. 2015. The Rise and Fall of Great Powers in the Twenty-First Century. China's Rise and the Fate of America's Global Position, International Security, 40(3), Winter 2015/16: 7-53.

Cabestan, Jean-Pierre. 2015. China-Cameroon Relations: Fortunes and Limits of an Old Political Complicity, South Africa Journal of International Affairs, 22 (1):67-91.

Chaponnière, Jean-Raphael. 2009. Chinese Aid to Africa: Origins, Forms and Issues. In Meine Pieter Van Dijk (ed.), The New Presence of China in Africa, Amsterdam University Press. 
AFRICAN

EAST-ASIAN

AFFAIRS

Chaponnière, Jean-Raphael. 2013. La Chine et l'Afrique, l'enjeu minier, Afrique contemporaine, 248:89-105.

Chauvin, Sophie. 2012. Tanzanie: Analyse du risque pays et du risque souverain. Paris: Agence Française de développement, Division AMR.

Dollar, David. 2016. China's Engagement with Africa. From Natural Resources to Human Resources, Washington DC: The John L. Thornton China Center at Brookings.

Hanauer, Larry and Morris, Lyle. 2014. Chinese Engagement in Africa. Drivers, Reactions, and Implications for U.S. Policy, Washington DC: Rand Corporation.

Hermann, Richard. 2013. Perceptions and Image Theory in International Relations. In Leonie Huddy, David O. Sears, and Jack S. Levy (eds.), The Oxford Handbook of Political Psychology (2 ${ }^{\text {nd }}$ Edition), Oxford: Oxford University Press.

Jansson, Johanna, Burke, Christopher and Hon, Tracy. 2009. Patterns of Chinese investment, aid and trade in Tanzania: Briefing paper prepared for World Wide Fund for Nature (WWF), October 2009. South Africa: Centre for Chinese Studies, Stellenbosch University.

Kalu, Kelechi A., and Kieh, George Kay. 2014. United States-Africa Security Relations. Terrorism, regional security and national interests, London \& New York: Routledge.

Kamata, Ng'wanza. 2014. Perspectives on Sino-Tanzanian Relations. In Adem, Seifudein (ed.), China's Diplomacy in Eastern and Southern Africa. London: Ashgate.

Kuik, Cheng-Chwee. 2008. The Essence of Hedging: Malaysia and Singapore's Response to a Rising China, Contemporary Southeast Asia 30(2):159-185.

Kuik, Cheng-Chwee. 2016. How Do Weaker States Hedge? Unpacking ASEAN 
AFRICAN

EAST-ASIAN

AFFAIRS

States' Alignment Behavior Towards China, Journal of Contemporary China, 25(100):500-514.

Kweka, Josaphat and Lu, Y. 2013. Chinese Private Investments in Tanzania: Where to and where from, Draft, Washington DC: World Bank.

Lee, Ching Kwan. 2009. Raw Encounters: Chinese Managers, African Workers and the Politics of Casualization in Africa's Chinese Enclaves, The China Quarterly, 199 (September):647-666.

Li, Xing and Farah, Abudkadir Osman. 2013. China-Africa Relations in the Era of Great Transformations, Farnham, UK, and Burlington, VT: Ashgate Publishing.

Minde, Nicodemus. 2016. Magufuli's First 100 Days: Failed Diplomacy and Foreign Policy Approach?, Decolanga. [Online]. Available: http:// www.decolanga.com/magufulis-first-100-days-failed-diplomacy-and-foreignpolicy-approach/

Mponzi, Topisto. 2014. Challenges to the Implementation of Tanzania's New Foreign Policy, Saarbrücken, LAP Lambert Academic Publishing, Omniscriptum.

Onjala, Joseph. 2014. Merchandise Trading Between Kenya and China: Implications for the East African Community (EAC). In Adem, Seifudein (ed.), China's Diplomacy in Eastern and Southern Africa. London: Ashgate.

Pehrson, Christopher. 2006. String of pearls: Meeting the challenge of China's rising power across the Asian littoral. Carlisle, Penn.: Strategic Studies Institute, US Army War College.

Rotberg, Robert. 2008. China into Africa: Trade, Aid, and Influence. Washington DC: Brookings Institution Press.

Rutaihwa, Johansein Ladislaus and Mkwawa, Amina Ramadhan. 2011. Empirical Analysis of China-Africa Economic and Trade Cooperation for Good or Bad: 
AFRICAN

EAST-ASIAN

AFFAIRS

A Case of Tanzania, International Journal of Academic Research in Business and Social Sciences, 1(3):419-435.

Scott, David. 2008. The Great Power 'Great Game' between India and China: The Logic of Geography, Geopolitics, 13 (1):1-26.

Shinn, David and Eisenman, Joshua. 2012. China and Africa: A Century of Engagement, Philadelphia: University of Pennsylvania Press.

Shinn, David. 2016. Extended Ground for U.S.-China Competition? Comparing China and the U.S.' Engagement with Africa, China Quarterly of International Strategic Studies, 2(1):35-55.

Sigalla, Huruma Luhuvilo. 2014. Changing Trends in China-Tanzania Relationship. A sociological inquiry into the mixed perceptions of the Tanzania-China relationship on the eve of globalisation, Österreich Z Soziol 39:61-78.

SIPRI Arms Transfers Database. 2015. Database. [Online]. Available: http:// armstrade.sipri.org/armstrade/html/export_values.php

Sun, Yun. 2014. Africa in China's Foreign Policy, Washington DC: Brookings.

Taylor, Ian. 2009. China's New Role in Africa. Boulder, Colo.: Lynne Rienner Publishers.

Taylor, Ian. 2014. Africa Rising? BRICS - Diversifying Dependency. Woddbridge, Suffolk, \& New York: James Currey.

Tessman, Brock. 2012. System Structure and State Strategy: Adding Hedging to the Menu, Security Studies, 21(2):192-231.

Tunsjø, Øystein. 2011. Geopolitical shifts, great power relations and Norway's foreign policy, Cooperation and Conflict, 46(1):60-77.

UNIDO. 2012. Tanzania Competitiveness Report, Dar es Salaam: Ministry of Industry and Trade of the United Republic of Tanzania (MIT), President's Office Planning Commission of the United Republic of Tanzania (POPC) and 
AFRICAN

EAST-ASIAN

AFFAIRS

United Nations Industrial Development Organization (UNIDO).

UNCTAD. 2014. World Investment Report. Geneva:UNCTAD.

Vickers, Brendan. 2013. Africa and the Rising Powers: Bargaining for the 'Marginalized Many', International Affairs, 89(3):673-693.

Walt, Stephen. 2012. The Myth of Chinese Exceptionalism, Foreign Policy. [Online]. Available: http://foreignpolicy.com/2012/03/06/the-myth-of-chineseexceptionalism/

Wang, Yuan-kang. 2010. Harmony and War: Confucian Culture and Chinese Power Politics. New York: Columbia University Press.

Wangwe, Samuel, Mmari, Donald, Aikeali, Jehovanes, Rutatina, Neema, Mboghania, Thadeus, and Kinyondo, Abel. 2014. The Performance of the Manufacturing Sector in Tanzania: Challenges and the Way Forward. Washington DC.:Learning to Compete Working Papers.

Wasserman, Herman. 2015. Reporting China in Africa. Media Discourses on Shifting Geopolitics. Abingdon, Oxon \& New York: Routledge.

Womack, Brantly. 2010. China Among Unequals: Asymmetric Foreign Relationships in Asia. New Jersey: World Scientific.

World Bank. 2014. Tanzanian economic update, who wants a job, the magnetic power of cities. Dar es Salaam: World Bank.

Zhang, Xiaolin, Wasserman, Herman and Mano, Winston. 2016. China's Media and Soft Power in Africa. Promotion and Perceptions, Basingstoke, Hampshire \& New York: Palgrave MacMillan.

\section{Interviews}

1. Tian Ye, journalist, Xinhua Agency, Dar es Salaam, 1 January 2012.

2. Zhu Jinfeng, Director, Chinese General Chamber of Commerce in Tanzania 
AFRICAN EAST-ASIAN AFFAIRS

(Tanzaniya Zhonghua zongshanghui) and Director, T-Better Motorcycle Company, Dar es Salaam, 1 and 6 January 2012.

3. Stefan Reich, country representative, Richard Shaba, Korand Adenauer Stiftung, Dar es Salaam, 3 January 2012.

4. Western diplomat, Dar es Salaam, 3 January 2012.

5. Western defence attaché, Dar es Salaam, 4 January 2012.

6. Diplomat, Chinese Embassy, Dar es Salaam, 5 January 2012.

7. Mwasiga Baregu, Professor, Saint Augustine University, Dar es Salaam, 5 January 2012.

8. Ng'wanza Kamata, Professor, University of Dar es Salaam, Dar es Salaam, 5 January 2012.

9. Indian trader interviewed in the Karioko market, Dar es Salaam, 8 April 2012.

10. Shi Yingying, journalist, China Radio International, Nairobi, 18 December 2011. 